\title{
INFORMMAE
}

Doc. JUDr. PhDr. Miroslav Mareš, Ph.D., Mgr. Michael Murad

\section{Reflections over Syrian Conflict in the Czech Republic}

\begin{abstract}
Abstrakt:
Článek pojednává o tom, jakým způsobem je současný syrský konflikt reflektován v České republice. Představeny jsou zejména aktivity samotné syrské diaspory $v$ České republice, která je zde přtomna od dob komunistického režimu. Obdobně jako je tomu v Sýrii, $i$ v České republice nejsou Syřané zdaleka jednotní. Jsou mezi nimi jak lidé loajální režimu strany Baas a Bašára al-Asada, tak členové opozice. Ta se navíc v polovině roku 2012 rozštěpila na dvě skupiny. Představena je i reakce na konflikt řady subjektů z České republiky.
\end{abstract}

\section{Abstract:}

This study deals with the responses to recent Syrian conflict in the Czech Republic. The authors introduce particularly activities inside Syrian diaspora, actually formed during the time of communism. Syrian citizens living in the Czech Republic are not homogeneous, which is similar to the situation in Syria. In our country we can find both people loyal to the regime of Ba' ath Party and Bashar al-Assad, and also members of opposition that in fact has divided into two groups, since the mid-2012. The authors introduce reactions of various subjects from the Czech Republic.

\section{Klíčová slova:}

Syrská arabská republika, Sýrie, občanská válka, konflikt, sunnité, alávité, saláfismus, Kurdové, strana BAAS, Česká republika, diaspora, opozice, občanské sdružení, protesty.

Key words:

Syrian Arab Republic, Syria, civil war, conflict, Sunnis, Alawites, Salafism, Kurds, Ba'ath Party, Czech Republic, diaspora, opposition, civic society, protests.

\section{Úvod}

Již dva roky probíhá v Sýrii ozbrojený konflikt, který má výrazný vliv nejen na syrskou vnitropolitickou situaci, ale i na mezinárodní bezpečnost a na situaci v dalších zemích. Jeho dopady jsou pozorovatelné i v České republice. Syrská diaspora je zde 
aktivní již od dob normalizace, avšak k její výrazné veřejné politické aktivitě na území ČR dochází až v současnosti. Její současné rozštěpení podle politických preferencí ve spojení s demonstracemi a propagandou vytváří specifickou situaci, jejíž charakter je dokreslován i provázáním syrských skupin s českou občanskou společností, politiky, publicisty i se subjekty z prostředí krajní levice a krajní pravice. Ve středoevropské zemi tak aktivně působí aktéři, kteří ve veřejném prostoru tematizují problematiku blízkovýchodního státu. Popisu a stručné analýze odezvy syrského konfliktu v syrské diaspoře a spojencům jednotlivých stran v domácí politice se věnujeme i v tomto článku.

\section{Stručná charakteristika konfliktu v Sýrii}

Prapůvod syrského konfliktu lze vysledovat u událostí tzv. arabského jara, které vedlo k pádu některých autoritativních režimů v regionu Blízkého východu a severní Afriky a jejich nahrazení politickými režimy, v jejichž čele stojí převážně islamisté. Zatímco v Tunisku, či v Egyptě vedly demonstrace ke svržení dlouholetých politických elit, protesty Syřanů, které vypukly v březnu 2011 a které začaly být po počátečních ústupcích ze strany vládnoucího režimu potlačovány, nebyly završeny významnějšími demokratickými změnami. K pádu režimu prezidenta Asada a strany Baas nevedlo ani následné ozbrojené povstání (obdobné povstání přitom slavilo - za pomoci mezinárodní intervence - úspěch v Libyi). K vyřššní do značné míry patové situace v etnicky a nábožensky rozdělené zemi nepomáhají ani iniciativy mezinárodního společenství, zejména OSN a Ligy arabských států. [1]

Na situaci v Sýrii lze vysledovat několik stadií. I počáteční ústupky vlády z Damašku byly i první fázi konfliktu v Sýrii doprovázeny represemi, ty ovšem vyvolaly další protesty a snížily důvěryhodnost režimu. [2] Partikulární ústupky vlády vystř́ídala snaha o tzv. bezpečnostní řě̌ení celé situace, kdy pokusy vládních složek o podrobení si obyvatelstva dodaly opozici dalších sil a posunuly ji k ozbrojenému odporu. V současnosti jsme svědky tzv. vojenského řě̌ení, kdy je kvůli taktice spálené země a masivnímu ničení dříve národní armáda na mnoha místech vnímána jako okupační síla. [3]

Na jedné straně konfliktu (označovaného i za syrskou občanskou válku), který si k únoru 2013 vyžádal dle odhadu vysoké komisařky pro lidská práva Navi Pillay již takřka 70000 obětí, stojí ozbrojené jednotky loajální vládě, na straně druhé pak značně roztř́íštěná opozice. [4] Do nástupu syrského prezidente Bašára al-Asada, který stojí v čele vládní strany Baas a bezpečnostního aparátu země, v roce 2000 vkládalo mnoho lidí naděje, ostatně on sám slíbil při svém nástupu k moci rozsáhlé reformy zahrnující modernizaci ekonomiky, boj s korupcí a i určité změny v politické oblasti. Pozornost ale měla být soustředěna pochopitelně na reformy ekonomické. [5] Asadovou prioritou ovšem i nadále zůstávala vnitropolitická stabilita země a jakýkoliv náznak liberalizačních a demokratizačních procesů byl velmi záhy zastaven.

Arabské jaro se Sýrie začalo bezprostředně týkat v březnu roku 2011, kdy se objevily protesty v provincii Dará na jihu, které se následně rozšíriily i do dalších částí země. Syřané požadovali legalizaci všech politických stran, více politických svobod, propuštění politických vězňů, či zrušení výjimečného stavu. Aby mohla být snaha o demokratické změny v Sýrii úspěšná, bylo by potřebné vytvoření jednotné a efektivní opozice, ovšem jak pro opozici v exilu, tak pro opozici př́mo v Sýrii je charakteristická její značná roztříštěnost. Opoziční skupiny se neshodnou na postoji k případné mezinárodní intervenci 
či na formě dialogu se syrskou vládou. Ačkoliv se samozřejmě pokusy o vytvoření koalic opozičních hnutí ve snaze o jejich sloučení a o získání mezinárodního uznání objevily. [6]

Mezi nejvýznamnější syrské opoziční skupiny patří Národní koalice pro syrské revoluční a opoziční síly, na jejímž vzniku se opoziční frakce dohodly v listopadu roku 2012 na setkání v Kataru a zahrnuje členy jak přímo ze Sýrie, tak ze zahraničí. V rámci této koalice kontroluje pouze menšinu křesel dřive dominantní zastřešující opoziční skupina Syrská národní rada. Ta byla zformována v říjnu roku 2011 s cílem nabídnout mezinárodnímu společenství důvěryhodnou alternativu syrské vlády. V září 2011 byl vytvořen Národní koordinační výbor, který je sestaven ze třinácti levicových politických stran, tří stran kurdských a nezávislých politických aktivistů. Další ze skupin, Svobodná syrská armáda, byla vytvořena v srpnu 2011 v Turecku vojáky dezertujícími ze syrské armády. Její velení deklaruje, že má přibližně 40000 bojovníků, ovšem objevují se i hlasy, že jich je pouze 10 000. [7] Mimo výše zmíněné působí v Sýrii ještě další ozbrojené skupiny (včetně skupin teroristických), které stojí i za sebevražednými útoky a jsou militantně islamistické. Jmenovat můžeme např. Frontu al-Nusra (Národní fronta), která má přibližně 5000 členů. [8]

Ač je to opozicí samotnou zlehčováno a režimem naopak zveličováno, mezi opozičními rebely v Sýrii je přítomen silný saláfistický [9] prvek, což ovšem nelze zcela jednoznačně hodnotit jako silně znepokojující fakt, jelikož saláfismus představuje široký proud zahrnující jak umírněné, tak extremisty, a v Sýrii se jedná o prvek cizí. Dnešní Sýrie představuje pro saláfisty velmi pohostinné území - je zde přítomné násilí a sektářství; deziluze ze Západu, sekulárních vůdců a pragmatických islamistů; stejně tak má současná Sýrii blízko k Perskému zálivu a jeho finančním zdrojům a džihádistickým zkušenostem.

Na druhou stranu proti rozvoji saláfismu svědčí umírněná islámská tradice v zemi, pluralitně-konfesní charakter společnosti a všeobecně panující obavy ze sektářské občanské války, která zasáhla dvě sousední země (Libanon a Irák). Dalším faktorem je selhání ofenzivy z léta roku 2012, které vyvolalo odpor proti saláfistickým skupinám, jež poutaly pozornost médií během bojů. [10]

\section{Dění v Sýrii a Česká republika}

Syrsko-české resp. syrsko-československé vztahy mají dlouhou tradici, jejich současnou podobu však začala určovat až generace Syřanů, kteří přrišli na československé území v době komunistického režimu, zvláště v jeho normalizační a přestavbové éře. Komunistické Československo mělo se Sýrií relativně dobré vztahy, at již ve smyslu obecné vzájemné politické podpory socialistických režimů či konkrétních projevů v oblasti zbrojní studentské spolupráce. [11] Právě syrští studenti (genderově dominovali usídlení muži syrského původu) v ČR vytvořili základ současné syrské komunity v České republice, když si zde mnozí našli životní partnerky, měli děti a usadili se. Někteří z nich byli aktivní v opozičním hnutí proti baasistickému režimu, tudíž pro ně trvalý návrat do Sýrie nepřipadal v úvahu, a je přirozené, že ve svých aktivitách namírených proti současnému režimu pokračují i po vypuknutí syrského konfliktu.

Je velmi obtížné odhadnout, jak velká část Syřanů usazených v České republice se kloní na stranu opozice a jak velká část zůstává loajální Asadovu režimu. Dle odhadu 
samotných členů opozice je jejich rozložení přibližně (alespoň v Praze) vyrovnané. Část Syřanů se pak nekloní ani na jednu stranu. [12] Pakliže bychom ale vycházeli pouze z aktivit, které odpůrci režimu i jeho sympatizanti vyvíjejí, lze usuzovat, že je skupina opoziční daleko větší.

Syřané žijící v České republice jsou v pravidelném kontaktu se Syřany př́ímo v Sýrii, a to nejenom se svými rodinami, ale i s opozicí. Dochází k výměně kontaktů, informací i s opozičními skupinami mimo Sýrii, případně se stalo, že byla opozice v ČR oslovena se žádostí o zprostředkování pomoci skupině lékařù. Všechny tyto kontakty probíhají ale spíše na osobní bázi. [13]

Konflikt v Sýrii se bezprostředně dotkl i českých občanů. Hojně medializován byl v létě roku 2012 prrípad Sandry Bitarové, která je syrskou i českou občankou (její bratr Chalid je pak členem předsednictva Iniciativy pro svobodnou Sýrii). Sandra Bitarová byla nejprve (v březnu) zadržena na krátkou dobu, ovšem v červnu a v červenci strávila v syrské vazbě kvůli podezření ze spolupráce s Asadovými odpůrci 35 dní. Bitarová, která pochází ze smíšeného česko-syrského manželství, po svém propuštění, na kterém měla podíl i česká diplomacie, odešla do Prahy. Její otec studoval v Praze medicínu a byl členem Syrské komunistické strany, vymezoval se ovšem nejenom vůči baasistickému režimu, ale i vůči režimu v Československu, tudíž zde nemohl zůstat. [14]

Oficiální postoj České republiky k situaci v Sýrii je spíše zdrženlivý, což vyvolává odmítavé reakce nejenom přímo z řad syrské opozice. Kritice ze strany Syřanů žijících v České republice čelila i velvyslankyně České republiky v Sýrii Eva Filipi. [15]

Ve svém projevu se dne 25. září 2012 vyjádřil na 67. zasedání Valného shromáždění OSN k situaci v Sýrii i český prezident Václav Klaus, který zmínil nutnost poučení se z vojenské intervence v Libyi. „Není pochyb o tom, že situaci v Sýrii musíme vidět $v$ širši a delší perspektivě. Neměli bychom pouze vědět, co máme udělat dnes, ale také co máme udělat zítra a pozítří. “

Klaus řekl, že nyní Česká republika nevidí žádné uskutečnitelné řešení při syrské snaze o přechod k demokracii a apeloval na pomoc lidem zasaženým situací v zemi. Zároveň ve svém projevu zmínil i aktivity České republiky (přijetí žádosti USA o převzetí zastupování v diplomatických a konzulárních záležitostí v Sýrii, realizaci programu Medevac, či účast českých expertů na pozorovatelské misi OSN). Klaus tak jednoznačně varoval před intervencí, kdy se ve svém projevu i řečnicky zeptal, zdali jsou vývoj v Iráku, kyperská otázka nebo nezávislost Kosova úspěchy OSN. [16]

Obecnou pomoc všem civilistům v syrském konfliktu požaduje Prohlášení solidarity se syrskými civilisty a apel na otevření všech koridorů pro humanitární pomoc, za kterým stojí Věra Roubalová Kostlánová a František Kostlán. Autoři zde upozorňují na krizi dosahující děsivých rozměrů a vyzývají k lepší distribuci humanitární pomoci přímo v Sýrii. K této iniciativě se připojily některé nevládní organizace a známější osobnosti, např. Tomáš Halík, Eliška Wagnerová, Olga Sommerová, Ondřej Liška.

\section{Syrské opoziční skupiny v ČR a jejich podpora}

V České republice působí v současnosti (březen 2013) dvě občanská sdružení orientovaná na revoluční dění v Sýrii. Tím prvním je Iniciativa pro svobodnou Sýrii, která vznikla 20. 2. 2012, druhým sdružením je Sdružení svobodné syrské komunity v ČR, 
které bylo registrováno dne 11. 6. 2012. [17] Iniciativa se dle svých stanov soustředí na čtyři cíle:

1. Sdružování osob žijících na území ČR, kteří podporují osvobození Sýrie od diktatury a nastolení civilizovaného pluralitního demokratického režimu, který by zajišt’oval rovnoprávnost všem Syřanům bez ohledu na rasu, náboženské prŕíslušnosti a pohlaví.

2. Upevňovat přátelské vazby mezi členy pořádáním různých protestních aktivit proti stávajícímu syrskému režimu na straně jedné, a jiných kulturních a společenských aktivit na straně druhé.

3. Podporovat syrský lid všemi možnými prostředky v souladu s českým právem v jeho boji za svobodu.

4. Objektivně informovat českou společnost o situaci v Sýrii a hrdinný boj Syřanů za svobodu a demokracii přes sdělovací média a různé jiné kulturní akce. [18]

Jako klíčové úkoly Iniciativy jsou vnímány ovlivnění veřejného mínění o syrské revoluci a pomoc revoluci samotné. „Máme dva základní úkoly-pomoc s medializací syrské revoluce, tak aby byla vnímána jako revoluce, a ne jako občanská válka. Aby lidé poznali přesně co se děje, protože v ČR vládnou různé myšlenky ohledně dění v Sýrii, snažíme se to korigovat, bohužel nejsme tak silní, abychom to zkorigovali všechno, ale snažíme se. Druhá věc je podpora syrské revoluce, humanitární pomoc uprchlíkům. “ [19]

V čele Iniciativy pro svobodnou Sýrii, která je podstatně větší než druhé sdružení, stojí Mazen Maialeh. Dalším členem výboru je např. předseda Kurdského občanského sdružení Rachid Khalil. Právě Kurdové hrají v Iniciativě významnou úlohu, nebot' naprostá většina aktivit Kurdského občanského sdružení se od roku 2011 orientuje díky charakteru kurdské komunity v ČR (značnou část tvoří Kurdové právě ze Sýrie) na situaci v Sýrii. Kurdové tvořili významnou část účastníků a řečníků na demonstracích před syrskou ambasádou v Praze, stejně tak se na těchto demonstracích objevovala kurdská vlajka.

Sám předseda Iniciativy si aktivit Kurdů v jejím rámci cenní: „Kurdové jsou jako komunita lépe stmeleni, než zbytek Syřanu․ To, co lze u Kurdi̊ pochválit, je to, že se dokážou dát dohromady a dokážou vytvořit nějakou reálnou sílu. O ostatních Syřanech se to ř́ci nedá, přeci jen režim dokázal v těch Syřanech vypudit, či naopak povzbudit všechny ty snahy o odlišnost a dokázal je do určité míry znesvářit. Vzbudil v Syřanech prvky, které nevedou ke stmelení. To stále pocitujeme a to je škoda. Kurdové jsou v rámci Iniciativy právem respektováni a já jsem tomu rád. “ [20]

V Iniciativě jsou však zastoupeny všechny etnické a náboženské skupiny Sýrie. Za jejím vznikem stojí více osob, které cítily spolu se začátkem pořádání protestů, potřebu se organizovat. Dříve zde žádná taková organizace Syřanů - až na ty prorežimní - nebyla. Do př́ípravy vzniku Iniciativy se zapojily i některé české nevládní organizace (např. Člověk v tísni), dnes probíhá spolupráce z větších neziskových organizací ještě s Organizací pro pomoc uprchlíkům či s Adrou. [21]

Zakládající schůze Iniciativy se zúčastnil i Hammam Yousef, člen Syrské národní rady, který byl pozván i na debatu spojenou s promítáním filmu v rámci festivalu Jeden svět, který organizuje Člověk v tísni. [22] Zakládající schůze Iniciativy proběhla dne 11. 3. 2012 a krom výše zmíněných se jí zúčastnili např. i člen krajského vedení Strany 
zelených v Ústí nad Labem Adam Souček, Daniela Pettrichová z Poradny pro integraci či Pavla Rozumková z Organizace pro pomoc uprchlíkům. V proslovech členů Iniciativy a pozvaných hostů v hojné míře zazněla krom volání po potřebě organizace opozice i kritika postoje české vlády, která vztahy se Sýrii nepřerušila a je jí vytýkána malá angažovanost. [23]

Jak je patrné, Iniciativa si klade za cíl i informování české společnosti a působení na ní, kdy chtějí ukázat „,skutečnější obraz, než jaký mohou průběžně dostávat z. médii““. [24] Iniciativa je tak v kontaktu s médii, ovšem její členové si stěžují na to, že vzhledem k závažnosti konfliktu v Sýrii mají čeští novináři o konflikt jen minimální zájem. Vidí v tom odraz české politiky, kterou označují za alibistickou, nezájem médií zdůvodňují tím, že pokud by zde bylo dostatečné zpravodajství, postoj české vlády by se ukázal být neadekvátním. Postoj české vlády se snaží změnit, ovšem uvědomují si své velmi omezené možnosti, absolvovali kupř́íkladu schůzku na Ministerstvu zahraničních věcí.

„Naše práce by měla být soustředěna na Čechy, lidé v demokracii vytvářejí nátlak na vládu. V tom bychom mohli dosáhnout našich cúlů. Cesta bude dlouhá a nejsme orientovaní přesně na toto, ale třeba setkání Syřanů v ČR by bylo setkání Syranů a přátel Sýrie. Všichni Čěsi, kteři mají cokoliv společného se syrskou otázkou, jsou zvaní. Budou tam materiály o Sýrii. Snažíme se mluvit směrem k české veřejnosti, uznávám, že je to slabé, ale snažíme se přes novináře atp. Musíme působit na vládní složky, i na ty Syřany, kteři jsou zde. Je jich málo, ale nekomunikují spolu. Česká veřejnost by měla vědět, co dělají. “ [25]

Krom informování o situaci v Sýrii se aktivity Iniciativy koncentrují převážně na organizování protestních akcí, přednášek, sepsána byla výzva vládě ČR k přerušení diplomatických styků se Sýrií, dne 21. března 2013 se pak uskutečnil v pražském kulturním domě Ládví i Koncert pro Sýrii, jehož výtěžek by měl být určen na humanitární pomoc Sýrii. V loňském roce se Iniciativě rovněž podařilo uspořádat humanitární sbírku v hodnotě přibližně jednoho milionu korun a odeslat ji do Sýrie. Ta byla v listopadu 2012 letecky dopravena do Jordánska, kde byla předána partnerské organizaci - Jordánské organizaci solidarity. [26] Na této sbírce se podílela Organizace pro pomoc uprchlíkům, kostel sv. Ignáce, Člověk v tísni a iniciativa syrskarevoluce.cz. Demonstrace se konají většinou před syrským velvyslanectvím v Praze, zorganizován byl i pochod k Velvyslanectví Ruské federace, stejně tak jako protestní shromáždění před Úřadem vlády, či na Václavském náměstí (blíže viz prríloha). Sdružení se prezentovalo kupříkladu i na pražském festivalu RefuFest. Demonstrace odpůrců režimu se neomezují pouze na Prahu, přibližně 25 Syřanů protestovala 17. února 2012 i v Plzni. [27] Další protesty se uskutečnily i v Brně.

Členy Iniciativy (kterých je přibližně 50) jsou jak Syřané, kteří zde žijí delší dobu, tak děti Syřanů zde usazených. I ti, kteří mají jednoho za jednoho z rodičů Čecha a neovládají ani arabštinu. Situace ohledně přesného počtu členů je v tuto chvíli nejasná, jelikož došlo ke vzniku novějšího sdružení, které je představeno níže. Předseda Iniciativy má do budoucna představu, že by se toto uskupení mohlo stát jakousi platformou pro všechny Syřany, kteří žijí v České republice, bez náboženských, etnických a politických rozdílů a Iniciativu tak vnímá jako dlouhodobější projekt. [28]

Jak jsme již zmínili, druhou syrskou opoziční skupinou působící v České republice je Sdružení svobodné syrské komunity v ČR, jehož ustavující schůze se uskutečnila 
28. 7. 2012. [29] Den předtím uspořádalo toto sdružení protirežimní demonstraci na Václavském náměstí. Dle svých stanov se Sdružení soustředí na obdobné cíle jako výše představená Iniciativa:

1. Sdružování osob žijících na území ČR, kteří usilují o svobodu, demokracii a nastolení spravedlnosti v Sýrii.

2. Podporovat syrský lid všemi dostupnými prostředky v souladu s českými zákony.

3. Vyvíjet činnosti a prezentovat syrský lid v oblasti kultury, vzdělání a tradice.

4. Podpořit a zastřešovat humanitární pomoci směřující do Sýrie. [30]

Členy sdružení jsou lidé, kteří dříve působili v Iniciativě pro svobodnou Sýrii a lze je označit za (nábožensky) radikálnější. Alespoň zpočátku vznik tohoto sdružení vyvolal v syrské komunitě rozkol. Členové obou sdružení se navzájem označovali za zrádce a obviňovaly se z touhy po zisku křesel v opozici v Sýrii. K rozporům v rámci komunity opozičních Syřanů došlo na začátku léta, v jeho průběhu pak byla vyvíjena snaha o smír v rámci opozice. Uskutečnila se jednání, kterých se účastnili lidé mající kontakty v obou skupinách. Nyní by již ale měla být situace klidnější a obě sdružení proti sobě nevystupují, ale pracují na „své věci“" samostatně.

„Sdružení svobodné syrské komunity v ČR se chtělo spíše identifikovat jako ta pravá skupina, která je radikálnější složkou opozice a príliš se neuměla integrovat do té mozaiky, která je v Iniciativě. Jsou tam i tyto di̊vody. Jsou to lidé, kteři chápou revoluci jako revoluci islámskou, a že my, co nesdílíme tento pohled, tak jako bychom nepatrili. Jim trošku vadí, že máme takový pohled liberálnější, že chceme stát opravdu demokratický, pluralitní, a tak mají jiný pohled. Chtějí mít stát nábožensky založený. “ [31]

Syrské opoziční dění podporuje i neformální iniciativa syrskarevoluce.cz, která vznikla v roce 2012 v Brně. Je tvořena převážně Čechy, výraznou roli v ní má studentka Klára Bažantová. Usiluje „o vybudování komunity, která společnými akcemi, mediálními výstupy a veřejným působením rozšírí povědomí o syrské revoluci mezi českou společností “. [32] Na jejích akcích participují i osoby z řad syrské opozice, což se projevilo zvláště na předvánočním setkání v Brně v prosinci 2012.

\section{Syrské prorežimní struktury v ČR a jejich podpora}

Struktury loajální režimu nevytvářejí na území ČR vlastní nové organizace. Jsou vázány na aktivity syrského velvyslanectví v Praze, na dlouhodobě působící Národní svaz syrských studentů v České republice [33] a na volnou strukturu stoupenců režimu po celém území republiky. Vyloučit nelze ani aktivitu syrských tajných služeb v podpoře této sítě a v monitorování politické opozice, protože to odpovídá dlouhodobým trendům činnosti vnější složky Ředitelství všeobecné bezpečnosti (Idarat al-Amn al-'Amm) v ČR. [34] Možné jsou i aktivity Vojenské zpravodajské služby (Shu'bat al-Mukhabarat al- 'Askariyya) a Zpravodajské služby vojenského letectva (Idarat al-Mukhabarat al-Jawiyya) s ohledem na relativně velký počet bývalých syrských vojáků a letců v ČR mezi syrskou komunitou v ČR.

Jak je již zmíněno výše, daleko více akcí organizuje v České republice syrská opozice, objevují se ovšem i akce na podporu režimu. Jednou z nich bylo i shromáždění, které se uskutečnilo 17. 3. 2012. To se zaměřovala na odpor vůči případné zahraniční 
politické či vojenské intervenci v Sýrii ze strany USA, Izraele, NATO a jejich regionálních spojenců. Demonstraci organizovali Syřané žijící v ČR a objevili se na ní krom oficiálních syrských vlajek i obrazy Bašára Al-Asada. [35] Krátká videoreportáž se objevila i na stránkách Českého mírového hnutí, které o akci informovalo. [36] Další z prorežimních akcí byla demonstrace solidarity se syrským lidem na Václavském náměstí, která se konala 20. ř́ína 2012 a organizoval ji Národní svaz syrských studentů v České republice. Na demonstraci vystoupil i člen ÚV KSČM Milan Krajča, kterému se budeme věnovat níže. Ten zde představil postoj, který zaujímá KSČM. [37] Bez zajímavosti jistě není, že zpráva o této solidární akci i s fotografií se objevila i na anglickém webu syrské vládní zpravodajské agentury SANA. [38] V článku se hovoří o odsouzení teroristických akcí, volání hesel zdůrazňujících národní jednotu, odmítnutí zahraničního vměšování a souhlasu s reformami prováděnými syrským vedením na pražské demonstraci. [39]

Miroslav Krajča do Sýrie zavítal i jako účastník tzv. pozorovatelské mise, [40] kterou organizovala Světová federace demokratické mládeže a Světová rada míru. Krajča o svých zkušenostech sepsal několik článků, které se objevily v Haló novinách, či na webu Komunistického svazu mládeže. Zároveň uspořádal v budově KSČM přednášku o své misi. Na tu zavítali i Syřané žijící v České republice, jak odpůrci režimu, tak jeho sympatizanti, a její průběh narušovali. [41] Na Facebookovém profilu Iniciativy pro svobodnou Sýrii je Krajča obviňován z toho, že se mise zúčastnil na základě pozvání syrského velvyslanectví v Praze a že celá návštěva země proběhla v režii syrské vlády.

Podpora syrskému režimu je vyjadřována i částí krajní pravice v ČR, i když to pro ni nepředstavuje nosné téma. Č́st neonacistů, neofašistů a vyhraněných nacionalistů je inspirována pojetím baasistů jakožto panaarabských nacionalistů, s nimiž evropští nacionální socialisté dlouhodobě spolupracují. Propagační videa, články a fotografie ve prospěch režimu Bašára Al-Asada, včetně fotografií mladých syrských stoupenkyň jeho režimu, byly zveřejněny na serveru revolta.info, blízkého autonomním nacionalistům. [42]

Tato část politického spektra podporuje i Evropskou frontu solidarity pro Sýrii (ESFS - European Solidarity Front for Syria), [43] která v ČR začala působit na počátku roku 2013. Čeští zástupci se spolu se zástupci ze Španělska, Finska, Belgie a Itálie zúčastnili i koordinační schůzky ESFS v Ř́mě dne 1. června 2013 a avizovali i svoji účast na Světovém shromáždění solidarity pro Sýrii v tomto městě 15. 6. 2013. [44]

\section{Závěr: Projevy syrského konfliktu v České republice}

Veřejné projevy syrského konfliktu v České republice se soustřed'ují především na demonstrace, při nichž však nedochází ke konfrontaci znepřátelených skupin. Shromáždění př́znivců a odpůrců režimu jsou uskutečňována v rozličnou dobu. Obě znepřátelené strany se však monitorují, v monitoringu opozice jsou aktivní i syrské tajné služby. Pokud je známo, nedošlo doposud k násilné konfrontaci. Za násilí je sporné označit házení vajíček proti syrskému velvyslanectví na jedné demonstraci.

Syřané stojící na straně opozice a ti, kteří zůstávají loajální režimu, na sebe útočí ve virtuálním prostředí. Na Facebooku se objevila stránka mapující ty, kteří jsou označováni za př́isluhovače a agenty baasistického režimu. [45] Na druhou stranu 
se na sociálních sítích objevily i příspěvky obviňující členy opozice v ČR ze spolupráce s režimem, ve snaze způsobit mezi nimi další rozkol. Také se objevilo několik lidí, kteří začali spolupracovat s Iniciativou, ovšem záhy zmizeli. [46]

Obecně se zatím aktivita syrských zneprrátelených skupin a jejich podpora ze strany části domácí politické scény a občanské společnosti nestala dominantním vnitropolitickým tématem v ČR. Nicméně samotný fakt relativně silné politizace blízkovýchodního konfliktu skupinami z prostředí diaspory je v ČR novinkou, i když dílčí projevy bylo možné pozorovat již u některých dřívějších událostí (Irák, Libye apod.). Z aktivit syrských opozičních a prorežimních skupin doposud nevzniklo ani žádné závažné bezpečnostní riziko pro ČR.

Tento text byl zpracován v rámci projektu specifického výzkumu katedry politologie FSS MU „Volby, politické strany a prosazování zájmü“ (kód MUNI/A/0742/2012).

\section{Poznámky k textu a literatura:}

[1] Současný konflikt nepredstavuje jedinou ozbrojenou revoltu za doby vládnutí strany Baas a dynastie Asadů, je ovšem zdaleka nejkrvavější. Země se ocitla na pokraji občanské války již na počátku 80 . let, kdy syrská armáda krvavě potlačila povstání islamistických sil ve městě Hamá. Vládní jednotky tehdy v roce 1982 reagovaly na útoky ze strany Muslimského bratrstva, které útočilo na od konce 70 . let na členy strany Baas, či na osoby spjaté s vládnoucím režimem. V několikadenních bojích byla zničena velká část města a odhady hovoří o 10000 až 25000 obětech (Ponížilová, Martina: Sýrie. In Burgrová, Helena - Ježová, Michaela (eds.). Současný Blizký východ. Politický, ekonomický a společenský vývoj od druhé světové války do současnosti. Brno: Barrister \& Principal, 2012, s. 105-11).

[2] Již v dubnu 2011 byl např. zrušen přibližně 48 let trvající výjimečný stav či byl schválen zákon umožňující pokojné manifestace. Dalším př́íladem ústupkủ režimu může být i udělení občanství části Kurdủ žijících v syrském regionu Hasaká, kteří se rovněž připojili k protestům proti režimu.

[3] Syria's Mutating Conflict [online]. International Crisis Group. 2012 [cit. 2013-03-08]. Dostupné $\mathrm{z}<\mathrm{http}$ ///www.crisisgroup.org/en/regions/middle-east-north-africa/egypt-syria-lebanon/syria/128-syrias-mutating-conflict.aspx $>$.

[4] Security Council must unite to protect civilians in conflict zones - UN officials [online]. UN News Centre, 2013 [cit. 2013-03-08]. Dostupné z <http://www.un.org/apps/news/story.asp?NewsID=44127 $\& \mathrm{Cr}=$ protection+of+civilians\&Cr1\#.USetR6UQmYQ>.

[5] Bašár al-Asad je druhorozeným synem syrského diktátora Háfize al-Asada (prezidentem byl od roku 1971), který se chopil moci v roce 2000, po smrti svého otce. Rodina Asadů patří mezi největší a nejvlivnější náboženskou syrskou menšinu - alávity. Původně se Asad připravoval na kariéru oftalmologa, kdy část studií strávil dokonce i v Londýně. Na nejvyšší úřad v zemi se začal připravovat po smrti svého staršího bratra. Co se týká zahraniční politiky, tak pokračuje ve směru nastoleném jeho otcem - v nekompromisní politice vůči Izraeli, kdy podporuje i militantní skupiny jakými jsou Hamás a Hizballáh. V posledních letech Asad posiloval vazby s Íránem, stejně tak s Ruskem a Čínou, což jsou jeho spojenci i při potlačování povstání v zemi. In Profile. Syria‘s Bashar al-Assad [online]. BBC, 2011 [cit. 2013-03-08]. Dostupné z <http://www.bbc.co.uk/news/10338256>.

[6] Ponížilová, Martina: Sýrie. In BURGROVÁ, H. - JEŽOVÁ, M. (eds.) Současný Blízký východ. Politický, ekonomický a společenský vývoj od druhé světové války do současnosti. Brno: Barrister \& Principal, 2012, s. 105-117, s. 106; Profile. Syria‘s Bashar al-Assad [online]. BBC, 2011 [cit. 2013-03-08]. Dostupné z <http://www.bbc.co.uk/news/10338256>.

[7] Guide to the Syrian opposition [online]. BBC, 2012 [cit. 2013-03-08]. Dostupné z <http://www.bbc. co.uk/news/world-middle-east-15798218>.

[8] Syria. Islamist Nusra Front gives BBC exclusive interview [online]. BBC, 2012 [cit. 2013-03-08]. Dostupné $\mathrm{z}<\mathrm{http}: / / w w w . b b c . c o . u k / n e w s / w o r l d-m i d d l e-e a s t-21061018>$.

[9] Saláfismus představuje myšlenkový proud v rámci sunnitského islámu odvolávající se na odkaz předků prvních generací islámu. Upozorňuje na úpadkové tendence v rámci islámu a snaží se očistit islám od nemuslimských vlivů. Skupiny, které spojují saláfismus s politickým islámem, pak bývajî 
někdy zmiňovány v souvislosti s islámským radikalismem. In ČEJKA, M. Encyklopedie blizkovýchodního terorismu. 1. vyd. Brno: Barrister \& Principal, 2007. 223 s. ISBN 80-87029-19-4.

[10] Tentative Jihad: Syria's Fundamentalist Opposition [online]. International Crisis Group. 2012 [cit. 2013-03-08]. Dostupné z <http://www.crisisgroup.org/en/regions/middle-east-north-africa/egypt-syria-lebanon/syria/131-tentative-jihad-syrias-fundamentalist-opposition.aspx $>$.

[11] ZÍDEK, P. - SIEBER, K. Československo a Blizký východ v letech 1948-1989. 1. vyd. Praha: ÚMV, 2009, 394 s. ISBN 978-80-86506-76-0, s. 285.

[12] Rozhovor s Chalidem Bitarem uskutečněný spoluautorem textu, Praha, 9. 1. 2013.

[13] Rozhovor s Chalidem Bitarem uskutečněný spoluautorem textu, Praha, 9. 1. 2013; Rozhovor s Mazenem Maialehem uskutečněný autory textu, Praha, 25. 1. 2013.

[14] Syřanka se před režimem ukrývá v Praze [online]. Česká televize, 2012 [cit. 2013-03-08]. Dostupné z <http://www.ceskatelevize.cz/ct24/svet/199160-syranka-se-pred-rezimem-ukryva-v-praze>.; Rozhovor s Chalidem Bitarem, bratrem Sandry Bitarové, Praha, 9. 1. 2013.

[15] Eva Filipi byla kritizována nejenom opozicí, ale např. i v Deníku Referendum. In FILÍPKOVÁ, Lenka. Co všechno česká velvyslankyně na ČT 24 o Sýrii neřekla? Deník Referendum [online]. 2012 [cit. 2013-03-08]. Dostupné z <http://denikreferendum.cz/clanek/14012-co-vsechno-ceska-velvyslankynena-ct24-o-syrii-nerekla>.), s tím, že v podstatě přebírá syrskou vládní propagandu.

[16] KLAUS, Václav. Projev prezidenta republiky na 67. zasedání Valného shromáždění OSN [online]. 2012 [cit. 2013-03-08]. Dostupné z <http://www.klaus.cz/clanky/3194>.

[17] Pozoruhodné je, že webové adresy obou sdružení jsou si velmi podobné. V př́padě Iniciativy pro svobodnou Sýrii je to www.freesyria.cz, v př́ípadě Sdružení svobodné syrské komunity v ČR je to www. freesyrie.cz.

[18] Stanovy občanského sdružení Iniciativa pro svobodnou Sýrii [online]. Iniciativa pro svobodnou Sýrii, 2012 [cit. 2013-03-08]. Dostupné z <http://freesyria.cz/page/detail/84/149/stanovy-obcaskeho-sdruzeni-iniciativa-pro-svobodnou-syrii-dle-zak-c-831990-sb>.

[19] Rozhovor s Chalidem Bitarem uskutečněný spoluautorem textu, Praha, 9. 1. 2013.

[20] Rozhovor s Mazenem Maialehem uskutečněný spoluautorem textu, Praha, 25. 1. 2013.

[21] Rozhovor s Chalidem Bitarem uskutečněný spoluautorem textu, Praha, 9. 1. 2013.

[22] Rozhovor s Hammamem Yousefem se objevil i v časopisu Respekt. In Syřané se nenechají odradit [online]. Respekt.cz. 2011 [cit. 2013-03-08]. Dostupné z <http://respekt.ihned.cz/letem-svetem/ c1-51726660-syrane-se-nenechaji-odradit>.

[23] Zápis ze zakládající schi̊ze [online]. Iniciativa pro svobodnou Sýrii, 2012 [cit. 2013-03-08]. Dostupné $\mathrm{z}<\mathrm{http}: / /$ freesyria.cz/page/detail/84/150/zapis-ze-zakladajici-schuze $>$.

[24] Rozhovor s Mazenem Maialehem uskutečněný spoluautorem textu, Praha, 25. 1. 2013.

[25] Rozhovor s Chalidem Bitarem uskutečněný spoluautorem textu, Praha, 9. 1. 2013.

[26] Zpráva o sbírce pro Sýrii. Praha, 12. 11. 2012 [online]. Iniciativa pro svobodnou Sýrii, 2012 [cit. 2013-03-08]. Dostupné z <http://freesyria.cz/page/detail/114/174/zprava-o-sbirce-pro-syrii-praha$12112012>$.

[27] Skupina Syřanů protestovala v centru Plzně proti poměrům ve své vlasti [online]. iDnes.cz, 2012 [cit. 2013-03-08]. Dostupné z <http://plzen.idnes.cz/skupina-syranu-protestovala-v-centru-plzne-proti-pomerum-ve-sve-vlasti-1o7-/plzen-zpravy.aspx?c=A120217_144810_plzen-zpravy_alt>.

[28] Rozhovor s Mazenem Maialehem uskutečněný autory textu, Praha, 25. 1. 2013.

[29] Ministerstvo vnitra sdružení registrovalo již 11. 6. 2012 (se sídlem v Hradci Králové).

[30] Stanovy Sdružení svobodné syrské komunity v ČR [online]. Sdružení svobodné syrské komunity v ČR, 2012 [cit. 2013-03-08]. Dostupné z <http://www.freesyrie.cz/index.php/cz/component/k2/item/1-stanovy-sdru\%C5\%BEen\%C3\%AD-svobodn\%C3\%A9-syrsk\%C3\%A9-komunity-v-\%C4\%8Dr>.

[31] Rozhovor s Chalidem Bitarem uskutečněný autory textu, Praha, 9. 1. 2013.

[32] O nás [online]. Syrskarevoluce.cz, 2012 [cit. 2013-03-08]. Dostupné z <http://www.syrskarevoluce. cz/o-nas/>.

[33] Jeho oficiální název, registrovaný ministerstvem vnitra, je Svaz syrských studentů v ČSSR.

[34] MAREŠ, M. Terorismus v České republice. 1. vyd. Brno: Centrum strategických studií, 2005, 480 s. ISBN 80-93333-8-9.

[35] Na akcích organizovaných syrskou opozicí se i v České republice od konce roku 2011 objevují staré syrské vlajky, použité poprvé v roce 1932.

[36] Tzv. České mírové hnutí samo sebe označuje za mírovou, protiválečnou a antiimperialistickou organizaci. Vzniklo na základě hnutí vymezujícího se vůči vybudování americké vojenské základny v brdských lesích. Hnutí je členem Světové rady míru. Viz Demonstrace proti imperialistické agresi v Sýrii 
ve videoreportáži [online]. České mírové hnutí, 2012 [cit. 2013-03-08]. Dostupné z < http://www. mirovehnuti.cz/2012/03/demonstrace-proti-imperialisticke.html>.

[37] Demonstrace solidarity se syrským lidem [online]. České mírové hnutí, 2012 [cit. 2013-03-08]. Dostupné z <http://www.mirovehnuti.cz/2012/10/demonstrace-solidarity-se-syrskym-lidem.html>.

[38] O podpoře režimu strany Baas ze strany Národního svazu syrských studentů v České republice, syrských studentů, arabských studentů obecně či českých občanů se ale píše i v jiných článcích. Např̀ viz Solidarity Stands with Syria in Russia, Czech Republic and Spain [online]. SANA. 2012 [cit. 201303-08]. Dostupné z <http://www.sana-syria.com/eng/22/2012/12/08/456226.htm>; Syrians in France, Russia and Czech, Arab Bodies Condemn Israeli Aggression on Syria [online]. SANA. 2013 [cit. 2013-03-08]. Dostupné z <http://www.sana-syria.com/eng/22/2013/02/02/465056.htm>.

[39] Events in Solidarity with Syria in Italy, Czech Republic, Romania, Russia, Spain, Venezuela and Cuba [online]. SANA. 2012 [cit. 2013-03-08]. Dostupné z <http://sana.sy/eng/22/2012/10/20/448061. $\mathrm{htm}>$.

[40] M. Krajča působil jako šéfredaktor Mladé pravdy a je jedním z čelných představitelů Komunistického svazu mládeže, jehož byl dokonce předsedou.

[41] Záznam z přednášky je $\mathrm{k}$ dispozici na serveru youtube.com.

[42] Sýrie [online] Revolta 2012 [cit. 2013-03-08]. Dostupné z <http://solidarita-syrie.info/>.

[43] European Solidarity front for Syria - Czech Republic [online]. Revolta.info. 2012 [cit. 2013-04-22]. Dostupné $\mathrm{z}<\mathrm{http}: / /$ www.revolta114.blogspot.cz/>.

[44] Koordinační schůzka v Římě [online]. Evropská fronta solidarity pro Sýrii 2013 [cit. 2013-03-08]. Dostupné $\mathrm{z}<\mathrm{http}: / /$ solidarita-syrie.info/>.

[45] Tato stránka byla reflektována jak na webových stránkách Eretz.cz, tak i na blogu Lukáše Lhot’ana. Ten dále upozorňuje na to, že by se měly české bezpečnostní složky soustředit krom spolupracovníků Asadova režimu i na opozici, jelikož se podle signálů z muslimské komunity mezi nimi objevují i sunnistští extremisté. Lhot’an dále vyslovuje tezi, že za stránkami, které jsou anonymní, stojí právě ,islamisté, či islámští extremisté z České republiky, kteří chtějí využít mediálního mýtu o boji za demokracii v Sýrii k likvidaci svých nepohodlných konkurentů v České republice“. In LHOŤAN, L. Skrytá válka agentů syrských povstalců se syřany v České republice? Blog iDnes.cz [online]. 2012 [cit. 2013-03-08]. Dostupné $\mathrm{z}<$ http://lukaslhotan.blog.idnes.cz/c/241122/Skryta-valka-agentu-syrskych-povstalcu-se-syrany-v-Ceske-republice.html>; Víme, kdo jsou Syřané, kteří v Česku podporují diktátora Asada! Sleduje je BIS? [online]. Eretz.cz, 2012 [cit. 2013-03-08]. Dostupné z <http://eretz. cz/2012/01/vime-kdo-jsou-syrane-kteri-cesku-podporuji-diktatora-assada-sleduje-je-bis/>.

[46] Rozhovor s Chalidem Bitarem uskutečněný spoluautorem textu, Praha, 9. 1. 2013.

\section{Syrský konflikt stál 93 tisíc životů}

Boje v Sýrii trvají přes dva roky a nepřežilo je na 93 tisíc lidí. Ve své zprávě to tvrdí OSN, podle níž je mezi mrtvými 6500 dětí. Vyplývá z ní rovněž, že od loňského července měsíčně v Sýrii umírá v průměru pět tisíc lidí.

Úřad vysokého komisaře OSN pro uprchlíky (UNHCR) hledá u evropských vlád možnosti pomoci pro 1,6 milionu Syřanů, kteří opustili svou zemi kvůli občanské válce. OSN očekává, že do konce letošního roku se jejich počet vyšplhá na 3,45 milionu.

Mladá fronta E15, deník pro ekonomiku a byznys, č. 1395, pátek 14. 3. 2013, 24 s. ISSN 1803-4543, str. 15; http://aktualne.centrum.cz/hledani.phtml?type=archiv\&section=157. 